DOI: https://doi.org/10.32839/2304-5809/2021-5-93-26

УДК 343.13

Скідан Н.В.

Національний юридичний університет імені Ярослава Мудрого

\title{
ДО ПИТАННЯ ЗАСТОСУВАННЯ §1 (В) СТАТТІ 5 КОНВЕНЦІЇ ПРО ЗАХИСТ ПРАВ ЛЮДИНИ І ОСНОВОПОЛОЖНИХ СВОБОД У КРИМІНАЛЬНОМУ ПРОВАДЖЕННІ
}

Анотація. Розвиток кримінальних процесуальних відносин обумовлюе важливість проведення дослідження їх окремих аспектів. Так, Україна, ратифі-кувавши Конвенцію про захист прав людини та основоположних свобод ще у 1997 р., взяла на себе зобов'язання забезпечити загальне та ефрективне визнання і додержання проголошених у Загальній декларації прав людини та безпосередньо Конвенції прав, до того ж визнала обов'язковою юрисдикцію Свропейського суду з прав людини. Однак, і досі залишаються питання щодо тлумачення та правозастосування §1(b) ст. 5 Конвенції, який визначає випадки легального обмеження права особи на свободу та особисту недоторканість. В статті проаналізовано два аспекти §1(b) ст. 5 Конвенції, а також визначено умови, за наявності яких можна вважати правомірним обмеження права особи на свободу та особисту недоторканість. Зокрема, за невиконання судового рішення законним буде арешт чи затримання особи, коли: 1 . вона була повідомлена про винесення судового рішення щодо неї; 2. вона мала можливість виконати припис суду, але не зробила цього. У свою чергу, арешт чи затримання особи для забезпечення виконання будь-якого обов'язку, встановленого законом, буде вважатися правомірним обмеженням права на свободу та особисту недоторканість, коли: 1. зобов'язання, покладене на неї, е точним і конкретним; 2. воно не може бути виконано більш м'яким способом. Визначено, що національними прикладами дії $§ 1$ (b) ст. 5 ЄКПЛ е: ст. 140, ч. 3 ст. 187, ст. ст. $188-191$, ч. 3 ст. 236 , ч. 6 ст. 237 , ч. 1 ст. 323 , ч. 1 ст. 327 та ст. 476 КПК України, а також проаналізовано особливості їх застосування. Констатовано, що норми КПК відповідають механізму, визначеному Конвенцією. Проте з аналізу національної судової практики можна дійти висновку про наявність помилкового підходу в окремих випадках застосування певних правових положень у цій площині.

Ключові слова: кримінальне провадження, право на свободу та особисту недоторканість.

Skidan Nataliia

Yaroslav Mudryi National Law University

\section{IN RELATION TO THE APPLICATION OF ARTICLEE 5, §1 (B), OF THE CONVENTION FOR THE PROTECTION OF HUMAN RIGHTS AND FUNDAMENTAL FREEDOMS IN CRIMINAL PROCEDURE}

Summary. The development of criminal procedure makes it important to conduct a study of its individual aspects. Ukraine, having ratified the Convention for the Protection of Human Rights and Fundamental Freedoms in 1997, has undertaken to ensure the general and effective recognition and control of the rights proclaimed in the General Declaration of Human Rights and in the Convention itself, it also recognized the compulsory jurisdiction of the European Court of Human Rights. However, there are still questions about interpretation and enforcement $\S 1$ (b) article 5 of the Convention, which regulates cases of legal restriction of a person's right to liberty and security of person. The article analyzed two aspects of $\S 1$ (b) of article 5 of the Convention for the Protection of Human Rights and Fundamental Freedoms and the conditions under which it may be considered lawful to restrict a person's right to liberty and security of person. In particular, failure to comply with a court decision would legitimately result in the arrest or detention of a person when: 1 . he has been informed of the judicial decision concerning himself; 2 . he has had the opportunity to comply with the court order but has not done so. In turn, the arrest or detention of a person for the purpose of enforcing any of the obligations established by law will be considered a lawful restriction on the right to liberty and security of person when: 1. the obligation incumbent upon him is precise and specific; 2 . it cannot be executed in a softer way. It has been determined that the national examples of $\S 1$ (b) of article 5 of the ECHR are: s. 140, s. 187(3), s. s. 188-191, s. 236, s. 237, s. 323, s. 327(1) and s. 476 of the Criminal Procedure Code of Ukraine and the specifics of their applica-tion were analysed. It is noted that the rules of the Code of Criminal Procedure correspond to the mechanism established by the Convention for the Protection of Human Rights and Fundamental Freedoms. However, from the analysis of national jurisprudence, it can be concluded that there is an erroneous approach in individual cases where certain legal provisions are applied in this context.

Keywords: criminal proceedings, right to liberty and security of person.

$\Pi^{\circ}$ остановка проблеми. Конвенція про захист прав людини та основоположних свобод (далі - Конвенція, ЄКПЛ) є фрундаментальним документом у галузі прав і свобод людини, який виступає реальним та дієвим засобом регламентації, забезпечення та захисту усіх гарантованих нею ідей. Україна, ратифікувавши Конвенцію, взяла на себе зобов'язання забезпечити загальне та ефрективне визнання і додержання проголошених у Загальній декларації прав лю- дини та безпосередньо ЄКПЛ прав, до того ж визнала для себе обов'язковою юрисдикцію Свропейського суду з прав людини (далі - ЄСПЛ, Суд) [1]. Тому Конвенція є частиною кримінального процесуального законодавства нашої держави (ст. 9 Конституції України [2], ч. 2 ст. 1 Кримінального процесуального кодексу України) [3].

Право на свободу та особисту недоторканість, гарантоване ст. 5 Конвен-ції, передбачає фізичну свободу людини; їі мета полягає в забезпеченні 
того, щоб жодна особа не могла бути свавільно позбавлена свободи [4, с. 9]. Воно вважається одним 3 найважливіших у кожному демократичному суспільстві, Україна - не є винятком. На національному рівні воно передбачено ст. 29 Конституції України [2] та ст. 12 Кримінального процесуального кодексу України (далі - КПК, Кодекс) [3]. Однак, є спірні питання щодо тлумачення та правозастосування цих положень, тому деякі 3 них будуть розглянути далі.

Аналіз наукових досліджень та публікацій. Право, гарантоване ст. 5 Конвенції, у кримінальному судочинстві було предметом наукового пошуку таких науковців як А. П. Бущенко, К. Д. Волков, С. В. Давиденко, В. В. Король, М. Є. Короткевич, В. І. Маринів, А. О. Побережник, Н. П. Черняк, В. Г. Уваров. Проте, ця проблематика потребує подальшого грунтовного дослідження, про що свідчать триваючі і досі дискусії у наукових колах та практичні виклики.

Метою даної статті $є$ виявлення існуючих на сьогодні проблемних питань у площині правового регламентування та застосування $\S 1(\mathrm{~b})$ ст. 5 Конвенції про захист прав людини та основоположних свобод у кримінальному провадженні, а також відшукання шляхів їх вирішення.

Виклад основного матеріалу. В пункті 1 статті 5 Конвенції кожному забезпечено право на свободу та особисту недоторканність. Винятками 3 цього права $є$ шість типів обставин, які сорормульовані в наступних положеннях і які є завершеним переліком виключень із загального правила. Іншими словами, Висока Договірна Сторона не має права створювати додаткові види підстав для арешту або затримання осіб, а повинна діяти в рамках, визначених Конвенцією. На додаток до џього Суд надав чітке роз'яснення винятків, підкресливши, що лише така інтерпретація відповідає завданням ціеї статті. Також цей пункт вимагає, щоб держава позбавляла свободи особу тільки «відповідно до процедури, встановленої законом». Ця вимога обмежує повноваження держави, тому що в практиці Комісії та Суду чітко встановлено, що термін «закон», який використовуеться в Конвенції, не означає виключно внутрішні законодавчі та підзаконні акти, а має більш широкий та об'єктивний зміст. Додатковою гарантією за цією нормою є те, що особа не може відмовитись від прав, які гарантовані йй у статті 5 [5].

Аналізуючи п. 1 ст. 5 ЄКПЛ, зауважимо, що варто відрізняти порушення права та його обмеження. Так, порушення права людини у крилінальнолу провадженні - це дії та рішення службових осіб, що застосовують процесуально-примусові заходи, не обумовлені фрактичними обставинами справи і не підтверджені належним чином сукупністю доказів у справі, а також пов'язані iз незаконними методами ведення дізнання та досудового слідства. У свою чергу, облеження прав $і$ свобод - випадки, передбачені законом, що мають тимчасовий, винятковий характер, коли без такого обмеження не можуть бути захищені права і свободи інших людей, інтереси суспільства і держави [6]. Отже, виходячи зі змісту ст. 18 Конвенції, можна дійти висновку, що їі п. п. a-f $\S 1$ ст. 5 е легітимними обмеженнями права на свободу та особисту недоторканність [1]. Однак, як свідчить практика, часто саме вони переростають у порушення, тому погоджуємося з висновками ЄСПЛ, що питання про те, чи особу було позбавлено свободи 3 порушенням ст. 5, має вирішуватись у кожній справі окремо з урахуванням усіх обставин [5].

Першим аспектол $\S 1(b) \mathrm{cm} .5$ Конвениіӥ є невиконання судового рішення, який передбачає, що заарештована або затримана особа мала можливість виконати припис суду та не зробила цього. До того ж жодну особу не може бути притягнуто до відповідальності за невиконання судового припису, якщо її не було повідомлено про нього.

Конвениійні інститути мають практику застосування першої частини статті 5 \& 1(b) в справах, що стосуються несплати судового штраббу, відмови у проходженні медичного обстеження, пов'язаного зі станол психічного здоров'я, або відмови здати аналіз крові за розпорядженнял суду, невиконання розпоряджень, що лиають обов'язкову силу, порушення улов звільнення під заставу $i$ помішення в психіатричну лікарню. Нащіональні органи повинні встановити справедливу рівновагу між важливістю забезпечення дотримання законного припису суду в демократичному суспільстві та необхідністю поважати право на свободу [4, с. 22-23].

Другий аспект статmі $5 \& 1$ (b) передбачає затрилання тільки для "забезпечення виконання" будь-якого зобов'язання, передбаченого законол. Тобто повинно мати місце невиконане зобов'язання, покладене на особу, а арешт і утримання під вартою мають проводитись 3 метою забезпечення його виконання, а не мати каральний характер. Щойно відповідне зобов'язання було виконано, підстава для затримання згідно зі ст. $5 \S 1$ (b) припиняе існування.

Так, зобов'язання має бути певної і конкретної природи, оскільки широке тлумачення спричинило б наслідки, несумісні з поняттям верховенства права. Зобов'язання не скоювати кримінальне правопорушення може вважатись "точним i конкретним» тільки тоді, коли місце і час ймовірного скоєння правопорушення, а також його потенційні потерпілі були зазначені 3 достатньою точністю. У випадку обов'язку утримуватись від певного діяння, на відміну від обов'язку вчинити конкретну дію, перш ніж дійти висновку про те, що особа не дотрималась згаданого зобов'язання, необхідно, щоб до її відома було заздалегідь доведено, що вона має утримуватись від скоєння конкретного діяння, а також, щоб ця особа виявила небажання утримуватись від таких дій.

Разом із тим, арешт буде прийнятним тільки якщо «обов'язок, передбачений законом», не може бути виконано більш м'якими засобами. Окрім того, принцип пропорційності передбачає необхідність встановлення рівноваги між важливістю забезпечити негайне виконання зобов'язання та важливістю права на свободу в демократичному суспільстві.

Ситуаиї̈, шо розглядаються иил аспектол cmammi 5 \& 1 (b), включають обов'язок пройти контроль на безпеку при вӥзді в країну, пред’явити відолості про свою особу, пройти психіатричне обстеження, з'явитися на допит в поліцейську дільницю, а також зобов'язання не порушувати гроладський порядок, тобто не скоювати крилінальне правопорушення [4, с. 23-24]. 
Узагальнюючи вищенаведене, вважаємо, шо треба виокрелити підстави, за допологою яких можна встановити праволірність арешту або затримання особи як облеження права, гарантованого ст. 5 Конвениї̈.

Тому, за невиконання судового рішення законним буде арешт чи затрилання особи у випадку, коли:

По-перше, особа була повідоллена про винесення судового рішення щодо неї. Однак, недостатньо лише поінорормованості про його існування, особа має знати і розуміти зміст обов'язків, що встановлені для неї у судовому рішенні.

По-друге, ия особа мала можливість виконати припис суду, але не зробила иього (дана можливість має бути реальною, а не абстрактною).

Арешт чи затрилання особи для забезпечення виконання будь-якого обов'язку, встановленого законол, буде вважатися праволірнил облеженнял права на свободу та особисту недоторканість за таких обставин:

По-перше, зобов'язання, покладене на особу, $\epsilon$ точнил і конкретнил.

По-друге, такий обов'язок не може бути виконаний більш м'якил способол. На нашу думку, обгрунтуванням цього пункту можуть бути дані, які підтверджують, що більш м'які засоби вже були застосовані та не дали результату або інші обставини, що доводять можливість забезпечення виконання даного обов'язку лише таким способом. Це є додатковою гарантією правомірності обмеження права особи та свідчитиме про його пропорційність.

3 систелного тлулачення норл крилінального процесуального Закону Украӥни вважаєло, шо національнили прикладали дї $\$ 1$ (b) $\mathrm{cm} .5$ ЄКПЛ є: 1) привід (cm. 140 КПК); 2) привід підозрюваного, обвинуваченого (ч. $3 \mathrm{~cm} .187 \mathrm{K \Pi К);}$ 2) затрилання підозрюваного, обвинуваченого 3 метою приводу (cm. cm. 188-191 КПК); 3) заборона будь-якій особі залишати місие обшуку до його закінчення та вчиняти будь-які дї, шо заважають його проведенню (ч. $3 \mathrm{~cm} .236$ КПК); 4) заборона будь-якій особі залишати місие огляду до його закінчення та вчиняти будь-які дї, шо заважають його проведенню (ч. $6 \mathrm{~cm} .237$ КПК); 5) привід обвинуваченого у випадку його неприбуття у судове засідання (ч. $1 \mathrm{~cm}$. $323 \mathrm{K \Pi К);}$ 6) привід свідка, який не прибув у судове засідання (ч. $1 \mathrm{~cm} .327$ КПК); 7) невиконання обвинуваченил угоди про прилирення або визнання винуватості (cm. 476 КПК) [3].

Так, першил прикладом з національного крилінального процесуального законодавства $\epsilon$ привід підозрюваного, обвинуваченого, регламентованій $\mathrm{cm} .140$ КПК (з урахуваннял ч. 1 cm. 323, ч. $1 \mathrm{~cm} .327$ КПК).

Привід полягає у примусовому супроводженні особи, до якої він застосовуеться, особою, яка виконуе ухвалу про здійснення приводу, до місця її виклику в зазначений в ухвалі час (ч. 1 ст. 140 КПК). Привід застосовуеться до особи, яка була зобов'язана з'явитися на виклик слідчого, прокурора, слідчого судді, суду, була викликана у встановленому цим Кодексом порядку (зокрема, наявне підтвердження отримання нею повістки про виклик або ознайомлення з їі змістом іншим шляхом), та не з'явилася без поважних причин або не повідомила про причини свого неприбуття (ст. ст. 140-142 КПК). Наслідками неприбуття на виклик $є: 1$. накладення грошового стягнення (ч. 1 ст. 139 КПК), 2. застосування приводу до підозрюваного, обвинуваченого, свідка (ч. 2 ст. 139 КПК) та 3. інша відповідальність, встановлена законом (ч. 3 ст. 139 КПК) [3].

Тому постає питання: якщо підозрюваний, обвинувачений, свідок не з'явився без поважних причин або не повідолив про причини свого неприбуття вперше, чи можливе одночасне застосування грошового стягнення $і$ приводу? Чи можливе застосування лише одного з них? Якшо так, то за яких улов?

3 аналізу Єдиного державного реєстру судових рішень слідує, що є різна практика: як з одночасним, так і з їх роздільним застосуванням.

Наприклад, Солонянський районний суд Дніпропетровської області своєю ухвалою від 24.06.2020 р. (справа № 192/196/20) дозволив одночасне застосування до свідка приводу та накладення на нього грошового стягнення за неявку останнього у судове засідання [7].

Воловецький районний суд Закарпатської області своєю ухвалою від 02.10.2020 р. (справа № 936/264/20) постановив здійснити привід обвинуваченого, який будучи належним чином повідомленим про час та місце слухання справи, на виклик не з явився, про причини неявки не повідомив [8].

Разом із тим, Тернопільский міськрайонний суд Тернопільської області в ухвалі від 08.10.2020 р. (справа № 607/12240/20) за неявку обвинуваченого в судове засідання наклав на останнього лише грошове стягнення [9].

На думку авторів, для вирішення цього питання варто погодитися 3 наступною пропозицією, виробленою наукою. У зв'язку з тим, що привід є кримінально-правовою санкцією та заходом примусу, то підстави його застосування не можуть тлумачитися поширювально, і якщо в КПК (мається на увазі п. 5 ч. 1 ст. 141 КПК) вказується на «факти виклику», то це як мінімум два таких факти. Таким чином, для застосування приводу наведення в клопотанні одного факту є недостатнім, йдеться про множину таких фрактів. Отже, для застосування до особи приводу в клопотанні про його здійснення повинні бути викладені не менше двох фрактів виклику особи і їі неприбуття на них без поважних причин (або без повідомлення причин свого неприбуття). У свою чергу, для накладення грошового стягнення достатньо і одного фракту неявки особи на виклик до компетентного органу [10, с. 212-213].

Підводячи підсулки за иил питаннял, зазначило, шо у випадку першої неявки підозрюваного, обвинуваченого, свідка на виклик уповноваженої особи без поважних причин або з неповідолленнял про причини свого неприбуття на них можна накласти лише грошове стлгнення. Толу полилковил є застосування приводу або одночасне накладення грошового стягнення та застосування приводу за таких обставин.

Проте, якшо така неявка є повторною (другий раз чи більше), то застосуванню підлягають положення ч. $2 \mathrm{~cm} .139$ КПК, яке викладено диспозитивно (про що свідчить наступне ббормулювання: "у випадку, встановленому части- 
ною першою иієї статmі, до підозрюваного, обвинуваченого, свідка може бути застосовано привід»). Тому вбачаємо, що слідчий суддя має певну дискрецію шодо вирішення иього питання. Однак, у КПК не лає прялої вказівки на те, що салие є злістол такої дискрецї̈, толу ие питання має бути вирішено законодавиел. 3 иього приводу пропонуєло врахувати наступне. У разі другої неявки особи нелає сенсу наклади ше раз грошове стягнення, оскільки його попереднє накладення не спричинило очікуваних наслідків $i$ особа знову була відсутня з неповажних причин. Тому на нашу дулку, наступним дієвил крокол має бути виключно застосування приводу.

Окрім цього, ухилення від явки на виклик слідчого, прокурора чи судовий виклик слідчого судді, суду (неприбуття на виклик без поважної причини більш як два рази) підозрюваним, обвинуваченим та оголошення його у міждержавний та/або міжнародний розшук $є$ підставою для здійснення спеціального досудового розслідування чи спещіального судового провадження (ч. 5 ст. 139 КПК) [3]. Отже, якщо буде встановлено, шо є підстави вважати про ухилення особи від явки на виклик слідчого, прокурора чи судовий виклик слідчого судді, суду, то наступною лірою $\epsilon$ оголошення підозрюваного, обвинуваченого у розшук.

Враховуючи усе вищенаведене, вважаємо, шо привід є проявол другого аспекту §1(b) cm. 5 Конвениї, оскільки повністю відповідає його ознакал, про які ми зазначали раніше у иій роботі, а салие:

1) Виклик (як ложлива передулова застосування приводу) $є$ точнил $i$ конкретнил зобов'язаннял тому, що воно (зобов'язання) сфрормульовано та викладено у певній процесуальній формі - повістці про виклик (ст. 137 КПК), яка складена відповідним уповноваженим суб'єктом (ст. ст. 133-134 КПК), такий виклик здійснюеться за відповідною процедурою (ст. 135 КПК).

2) Неложливість виконання обов'язку більш м'яким способом полягає у тому, що застосування такого більш м'якого засобу (яким у кримінальному процесі України є накладення грошового стягнення) не дало свого результату, тому до особи застосовуеться більш суворий засіб, яким $є$ привід.

Також варто розглянути питання приводу підозрюваного, обвинуваченого та його затриманнял з метою приводу як способу забезпечення прибуття останнього для розгляду клопотання про застосування запобіжного заходу (ч. $3 \mathrm{~cm} .183 \mathrm{ma} \mathrm{cm} . \mathrm{cm} .188-191 \mathrm{K \Pi К).}$

Питання обрання запобіжних заходів у кримінальному провадженні $є$ одним 3 ключових, оскільки одночасно стосуеться обмеження комплексу прав особи, а особливо - права на свободу та особисту недоторканість.

Метою їх застосування є забезпечення виконання підозрюваним, обвинуваченим покладених на нього процесуальних обов'язків, а також запобігання ризикам, визначених ч. 2 ст. 177 КПК. Вони застосовуються під час досудового розслідування - слідчим суддею за клопотанням слідчого, погодженим з прокурором, або за клопотанням прокурора, а під час судового провадження - судом за клопотанням прокурора. При цьому участь підозрюваного, обвинуваченого при розгляді такого клопотання є обов'язковою (ч. 1 ст. 193 КПК). Тому для забезпечення дії ціеї норми законодавець у ст. 187 КПК визначив засоби забезпечення прибуття особи для його розгляду, якими є: судовий виклик (ч. 1) та застосування приводу (ч. 3).

Так, у разі неприбуття підозрюваного, обвинуваченого за судовим викликом і відсутності у слідчого судді, суду на початок судового засідання відомостей про поважні причини, що перешкоджають його своєчасному прибуттю, слідчий суддя, суд має право постановити ухвалу про привід підозрюваного, обвинуваченого, якщо він не з'явився для розгляду клопотання щодо обрання запобіжного заходу у вигляді застави, домашнього арешту чи тримання під вартою, або ухвалу про дозвіл на його затримання з метою приводу, якщо ухвала про привід не була виконана (ч. 3 ст. 187 КПК) [3].

При цьму варто враховувати, що відповідно до ч. 1 ст. 188 КПК прокурор, слідчий за погодженням 3 прокурором має право звернутися із клопотанням про дозвіл на затримання підозрюваного, обвинуваченого з метою його приводу для участі в розгляді клопотання про застосування запобіжного заходу у вигляді тримання під вартою. Момент подання такого клопотання визначений у ч. 2 цієї ж норми, зокрема:

1. одночасно з поданням клопотання про застосування запобіжного заходу у вигляді тримання під вартою або зміни іншого запобіжного заходу на тримання під вартою. Толу слідчий суддя вирішуе иі питання одночасно, тобто призначає дату судового розгляду та постановляє ухвалу про дозвіл на затрилання підозрюваного, обвинуваченого з метою приводу.

2. після подання клопотання про застосування запобіжного заходу і до прибуття підозрюваного, обвинуваченого до суду на підставі судового виклику. Тобто спочатку слідчий суддя призначає дату судового засідання та здійснює виклик підозрюваного, обвинуваченого. I потіл після звернення слідчого, прокурора з клопотаннял про дозвіл на затримання з метою приводу, слідчий суддя прийлає відповідне рішення.

3. після неприбуття підозрюваного, обвинуваченого за судовим викликом для участі в розгляді клопотання про застосування запобіжного заходу у вигляді тримання під вартою і відсутності у слідчого судді, суду на початок судового засідання відомостей про поважні причини, що перешкоджають його своєчасному прибуттю. Отже, спочатку слідчий суддя призначає дату судового засідання та здійснюе виклик підозрюваного, обвинуваченого. I у випадку неприбуття останнього, а також з урахуваннял відсутносmi на початок судового засідання відомостей про поважні причини, шо перешкоджають його своєчаснолу прибуттю, прийлається рішення про дозвіл на затрилання підозрюваного, обвинуваченого з метою приводу [3].

Зі злісту иих положень зрозуліло, що вони також є проявол другого аспекту $\$ 1(b) \mathrm{cm} .5$ Конвенції. Адже, відповідність першій ознаці иього аспекту повністю зберігається, друга - також має місие, але з певнили особливостяли (при обранні запобіжного заходу у вигляді трилання під 
вартою єдинил засобол забезпечення прибуття особи є затрилання з метою ї̈ приводу, тобто немає попереднього більш м'якого засобу).

Вважаємо, що це пов'язано з метою застосування запобіжних засобів до особи, а особливо - найсуворішого. Оскільки, якщо 3 моменту виникнення підстав для його обрання цього не буде зроблено якнайшвидше, то ймовірні ризики, визначені у ч. 1 ст. 177 КПК, можуть стати реальними і тоді не буде досягнуто не тільки його мету, а навіть може не бути досягнуто завдань кримінального провадження в цілому, які передбачені у ст. 2 КПК.

Наступнил прикладол дї $\$ 1(b) \mathrm{cm} .5$ Конвениії у національнолу кримінальному прощесуальнолу законодавстві $\epsilon$ заборона будь-якій особі залишати лісие обшуку, огляду до їх закінчення та вчиняти будь-які дї̈, що заважають їх проведенню (ч. $3 \mathrm{~cm} .236 \mathrm{ma}$ ч. $6 \mathrm{~cm} .237 \mathrm{K \Pi К).}$

Так, згідно з ч. 3 ст. 236 та ч. 6 ст. 237 КПК слідчий, прокурор має право заборонити будьякій особі залишити місце обшуку (огляду) до його закінчення та вчиняти будь-які дії, що заважають проведенню обшуку. Невиконання цих вимог тягне за собою передбачену законом відповідальність [3].

Як свідчить національна судова практика, не завжди це положення правильно тлумачитися правозастосувачами, особливо - стороною захисту. Дуже часто таку вимогу захисники розцінюють як затримання у порядку ст. 208 КПК та пов’язують 3 порушенням §1(с) ст. 5 Конвенції.

Одним 3 прикладів є звернення захисника до слідчого судді Тернопільського міськрайонного суду Тернопільської області зі скаргою про те, що до підозрюваного було незаконно затримано під час проведення обшуку у його житлі. Однак, слідчий суддя з урахуванням положень Кримінального процесуального Закону України та виходячи з обставин справи, зазначив, що станом на 09 вересня 2020 року о 07 год 18 хв. (час проведення обшуку) не відбулось затримання підозрюваного в розумінні ст. 208 КПК. Насправді, затримання підозрюваного відбулося пізніше, про що було складено протокол в присутності підозрюваного та захисника [11].

Однак, варто зазначити, що з приводу вирішення цього питання було винесено власну правову позищію суддями Касащійного кримінального суду Верховного Суду (далі - ККС ВС). Так, у своїй постанові від 08.02.2021 р. (справа № 331/5362/15-к)
ККС ВС визначив, що обмеження в пересуванні ОСОБА_1 (під час проведення обшуку) не може свідчити про його фрактичне затримання як підозрюваного у вчиненні злочину, оскільки таке обмеження під час обшуку було здійснено відповідно до ч. 3 ст. 236 , а не ст. 208 КПК [12]

Підтримуючи позицію суддів ККС ВC, зазначимо, що вважаєло положення ч. $3 \mathrm{~cm} .236 \mathrm{ma}$ ч. $6 \mathrm{~cm} .237$ КПК наиіональнил прикладол втіленням ідеї §1(b) cm. 5 Конвениї̈, адже повністю відповідає ї̈ друголу аспекту. Такого висновку можна дійти, зважаючи на таке.

По-перше, даний обов'язок є точнил таконкретнил, оскільки його пряло сфборлульовано у

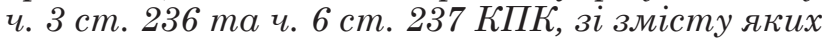
кожнолу об'єктивнолу спостерігачеві зрозуміло його суть. До того ж його метою $є$ не обмеження свободи особи, а досягнення мети обшуку (огляду) як слідчих (слідчих) розшукових дій, під час яких воно мало місце.

Так, метою обшуку є виявлення та фріксації відомостей про обставини вчинення кримінального правопорушення, відшукання знаряддя кримінального правопорушення або майна, яке було здобуте у результаті його вчинення, а також встановлення місцезнаходження розшукуваних осіб (ч. 1 ст. 234 КПК). Разом із тим, метою огляду е виявлення та фріксації відомостей щодо обставин вчинення кримінального правопорушення (ч. 1 ст. 237 КПК) [3]. Тобто ця заборона встановлюеться для того, аби досягти результату обшуку (огляду).

По-друге, забезпечити виконання такого обов'язку більш м'якил способол неложливо, толу шо він є ситуативнил, триває лише з моменту його оголошення слідчил, прокуророл та до лоленту закінчення обшуку (огляду). До того ж проникнення за ухвалою про дозвіл на проведення обшуку (огляду) дозволено один раз, тому така ситуативність потребує прийняття оперативного рішення, яким і є встановлення даного обов'язку. Отже, дана заборона відповідає вимогал §1(b) cm. 5 Конвениї̈.

Висновки. Не зважаючи на те, що певні положення КПК потребують уточнення законодавцем, в цілому норми кримінального процесуального законодавства України відповідають конвенційному механізму, визначеному в ЄКПЛ. Однак, у першу чергу, змін потребуе правосвідомість застосувачів, які інколи допускаються певних помилок попри те, що формулювання у КПК є досить чіткими та зрозумілими.

\section{Список літератури:}

1. Конвенщія про захист прав людини і основоположних свобод від 4 листопада 1950 p. URL: https://zakon.rada.gov.ua/ laws/show/995_004\#Text

2. Конституція України : Закон від 28.06.1996 р. № 254к/96-BP. URL: https://zakon.rada.gov.ua/laws/show/ $254 \% \mathrm{D} 0 \% \mathrm{BA} / 96-\% \mathrm{D} 0 \% \mathrm{~B} 2 \% \mathrm{D} 1 \% 80 \# \mathrm{Text}$

3. Кримінальний процесуальний кодекс України : Закон України від 13.04 .2012 № $4651-\mathrm{VI}$. URL: https://zakon.rada.gov.ua/laws/show/4651-17

4. Рада Європи, Свропейський суд з прав людини. Довідник із застосування статті 5. Право на свободу та особисту недоторканість. Стаття 5 Конвенції. 2014. URL: https://www.echr.coe.int/Documents/Guide_Art_5_ UKR.pdf

5. Гом'єн Д. Короткий путівник Європейською Конвенцією з прав людини. URL: http://www.arbitr.gov.ua/files/ pages/ECHR.htm

6. Назаров В. В. Конституційні права і свободи громадян у кримінальному провадженні - обмеження чи порушення? GOAL. 2014. URL: http://goal-int.org/konstitucijni-prava-i-svobodi-gromadyan-u-kriminalnomuprovadzhenni-obmezhennya-chi-porushennya/

7. Судова справа № 192/196/20 : Ухвала Солонянського районного суду Дніпропетровської області від 24.06.2020. URL: https://reyestr.court.gov.ua/Review/90005384 
8. Судова справа № 936/264/20 : Ухвала Воловецького районного суду Закарпатської області від 02.10.2020. URL: https://reyestr.court.gov.ua/Review/91983289

9. Судова справа № 607/12240/20 : Ухвала Тернопільського міськрайонного суду Тернопільської області від 08.10.2020. URL: https://reyestr.court.gov.ua/Review/92082628

10. Зіньковський I. П. Повноваження слідчого при неприбутті підозрюваного на виклик. Юридичний науковий електронний журнал. 2018. № 2. С. 212-214.

11. Судова справа № 607/15290/20 : Ухвала Тернопільського міськрайонного суду Тернопільської області від 11.09.2020. URL: https://reyestr.court.gov.ua/Review/91545655

12. Судова справа № 331/5362/15-к : Ухвала Касаційного кримінального суду Верховного Суду від 08.02.2021. URL: https://reyestr.court.gov.ua/Review/94874072

\section{References:}

1. Konventsiia Pro Zakhyst Prav Liudyny i Osnovopolozhnykh Svobod [Convention for the Protection of Human Rights and Fundamental Freedoms] (04.11.1950 r.). Available at: https://zakon.rada.gov.ua/laws/show/995_004\#Text

2. Konstytutsiia Ukrainy [Constitution of Ukraine]: Zakon vid 28.06.1996 r. № 254k/96-VR. Available at: https://zakon.rada.gov.ua/laws/show/254\%D0\%BA/96-\%D0\%B2\%D1\%80\#Text

3. Kryminalnyi protsesualnyi kodeks Ukrainy [Criminal Procedure Code of Ukraine]: Zakon Ukrainy vid 13.04.2012 № 4651-VI. Available at: https://zakon.rada.gov.ua/laws/show/4651-17

4. Rada Yevropy, Yevropeiskyi sud z prav liudyny (2014) Dovidnyk iz zastosu-vannia statti 5. Pravo na svobodu ta osobystu nedotorkanist. Stattia 5 Konventsii [Handbook on the implementation of article 5. Right to liberty and security of person. Article 5 of the Convention]. Available at: https://www.echr.coe.int/Documents/Guide_Art_5_ UKR.pdf

5. Homien D. Korotkyi putivnyk Yevropeiskoiu Konventsiieiu z prav liudyny [Short guide to the European Convention on Human Rights]. Available at: http://www.arbitr.gov.ua/files/pages/ECHR.htm

6. Nazarov V. V. (2014) Konstytutsiini prava i svobody hromadian u kryminalnomu provadzhenni-obmezhennia chy porushennia? [Constitutional rights and freedoms of citizens in criminal proceedings - restriction or violation?]. GOAL. Available at: http://goal-int.org/konstitucijni-prava-i-svobodi-gromadyan-u-kriminalnomu-provadzhenniobmezhennya-chi-porushennya/

7. Sudova sprava № 192/196/20: Ukhvala Solonianskoho raionnoho sudu Dnipropetrovskoi oblasti vid 24.06.2020. Available at: https://reyestr.court.gov.ua/Review/90005384

8. Sudova sprava № 936/264/20: Ukhvala Volovetskoho raionnoho sudu Zakarpatskoi oblasti vid 02.10.2020. Available at: https://reyestr.court.gov.ua/Review/91983289

9. Sudova sprava № 607/12240/20: Ukhvala Ternopilskoho miskraionnoho sudu Ternopilskoi oblasti vid 08.10.2020. Available at: https://reyestr.court.gov.ua/Review/92082628

10. Zinkovskyi I. P. (2018) Povnovazhennia slidchoho pry neprybutti pidozriuvanoho na vyklyk. [Powers of an investigator when a suspect is not summoned]. Yurydychnyi naukovyi elektronnyi zhurnal, no. 2, pp. $212-214$.

11. Sudova sprava № 607/15290/20: Ukhvala Ternopilskoho miskraionnoho sudu Ternopilskoi oblasti vid 11.09.2020. Available at: https://reyestr.court.gov.ua/Review/91545655

12. Sudova sprava № 331/5362/15-k: Ukhvala Kasatsiinoho kryminalnoho sudu Verkhovnoho Sudu vid 08.02.2021. Available at: https://reyestr.court.gov.ua/Review/94874072 